\title{
Role of the Endocannabinoid System in Anxiety and Stress-Related Disorders
}

\author{
Irit Akirav \\ University of Haifa \\ Israel
}

\section{Introduction}

Post-traumatic stress disorder (PTSD) is an anxiety disorder that may develop after exposure to a life-threatening traumatic experience and according to the DSM-IV diagnostic criteria, involves characteristic features such as persistent experiencing of trauma, avoidance, numbing, and hyperarousal (DSM-IV, 1994). Although many individuals with PTSD recover during the first couple of years following traumatic exposure, up to $30-40 \%$ remain chronically symptomatic (Kessler et al., 1995). Furthermore, individuals with chronic PTSD were shown to maintain conditioned fear responses to traumatic stimuli even 40-50 years after the trauma (Orr et al., 1993).

The largest body of treatment literature exists for antidepressants, particularly selective serotonin reuptake inhibitors (SSRIs). Extensive clinical experience with these agents and their efficacy for disorders that are commonly comorbid with PTSD means that their use will likely continue until better treatment options are found (Davidson, 2000; Ravindran \& Stein, 2009) even though their efficacy and that of other pharmacological treatments is generally limited. The high prevalence, chronicity, and resistance to treatment underscore the importance of the development of effective therapeutic strategies for PTSD.

The endocannabinoid (eCB) system has arisen as part of the complex circuitry that regulates anxiety and as a crucial mediator of emotional learning (Marsicano et al., 2002; Viveros et al., 2005; Laviolette \& Grace, 2006a,2006b; Gorzalka et al., 2008; Ganon-Elazar \& Akirav, 2009; Lutz, 2009; Hill \& Gorzalka, 2009; Parolaro et al., 2010). The idea that the eCB system is involved in the control of anxiety-like behaviour is rooted in the fact that Cannabis sativa is used recreationally, mainly for its euphoric effects. However, this picture is confounded by the fact that cannabis abusers sometimes experience dysphoric reactions, with feelings of anxiety and panic. Additionally, it has been suggested that a temporary form of drug-induced psychosis can occur in some cannabis users. This 'marijuana psychosis' is usually due to exposure to large doses of the drug (Iversen, 2003) and has similar symptoms to paranoid schizophrenia. This has led some to propose a 'cannabinoid hypothesis of schizophrenia', suggesting that the symptoms of schizophrenic illness might be caused by an abnormal over-activity of endogenous cannabinoid mechanisms in the brain (Emrich et al., 1997).

An interesting question in cannabis research is whether cannabis use can precipitate long-term psychiatric illness. There are several reports suggesting that the development of cannabis dependence in young people is associated with increased rates of psychiatric symptoms, including psychosis, depression and anxiety (Andreasson et al., 1987; Mathers \& 
Godse, 1992; Hall \& Degenhardt, 2000; Johns, 2001; Patton et al., 2002). In general, these studies do not prove any cause-and-effect relationship between cannabis use and long-term psychotic illness. Yet, cannabis can exacerbate the symptoms of existing psychotic illness. This of course will limit the therapeutic use of cannabis in people with existing psychotic illness (Iversen, 2003).

The psychoactive constituent of marijuana, delta-9-tetrahydrocannabinol (THC), was identified in 1964 (Gaoni \& Mechoulam, 1964) and this discovery led to the identification of the endogenous $\mathrm{eCB}$ system. This system includes cannabinoid receptors (CB1 and CB2), eCBs (anandamide and 2-arachidonoyl-glycerol [2-AG]), enzymes involved in their synthesis and metabolism (fatty acid amide hydrolase (FAAH) for anandamide and the monoacylglycerol lipase (MAGL) for 2-AG), and an eCB transporter (Devane et al., 1992; Freund et al., 2003; Kogan \& Mechoulam, 2006). Endocannabinoids are synthesized 'on demand' at post-synaptic sites of neurons after increase in neural activity and calcium ion influx, and are then released into the synaptic cleft. Their main function appears to be the suppression of neurotransmitter release from the presynapse. Thus, eCBs act as retrograde neurotransmitters, modulating other neurotransmitter systems.

Anandamide, 2-AG, FAAH, and the CB1 receptor are expressed in brain areas involved in stress, fear, emotions, and reward, including the amygdala, nucleus accumbens (NAc), hippocampus, and prefrontal cortex (PFC)(Herkenham et al., 1991; Freund et al., 2003; Pazos et al., 2005; Svizenska et al., 2008; Breivogel \& Sim-Selley, 2009). Hence, the significant changes in mood and anxiety induced by cannabis use are in accordance with the presence of CB1 receptors in these brain regions. $\mathrm{CB} 1$ and $\mathrm{CB} 2$ receptors belong to the superfamily of G protein coupled receptors (Devane et al., 1988; Howlett et al., 1990), the CB1 receptor is widely distributed in the terminals of neurons (Herkenham et al., 1991), while the CB2 receptor is extensively expressed throughout the immune system (Piomelli, 2003). However, it has recently been reported that these receptors are present also in the brain (Gong et al., 2006; Onaivi et al., 2006).

In this review, I will provide pre-clinical support for the view that the eCB system may represent a therapeutic target for the treatment of stress-related diseases and others characterized by an inability to extinguish maladaptive behaviours, in particular PTSD. Studies of the eCB system support its importance for multiple aspects of brain function, including modulation of the hypothalamic-pituitary-adrenal (HPA) axis, regulation of the stress response, anxiety, and extinction of fear learning (Viveros et al., 2007; Taber \& Hurley, 2009). I will give evidence that generally enhancing eCB signalling could represent a novel approach to the treatment of anxiety-related disorders whereas dysregulating the $\mathrm{eCB}$ system may result in anxiety and stress-related disorders. I will also focus on the role of the $\mathrm{eCB}$ system in brain circuits implicated in neuropsychiatric conditions, such as those modulating stress reactions, learning, extinction of fear, and emotional regulation (i.e., amygdala, NAc, hippocampus, and PFC) (Akirav \& Maroun, 2007; Jankord \& Herman, 2008).

\section{Role of the endocannabinoid system in stress, anxiety, and fear}

\subsection{The neurocircuitry of stress, anxiety and fear}

Stress is most readily defined as any stimulus that presents a challenge to homeostasis including any actual or potential disturbance of an individual's environment. The stress response enables the animal to adapt to the changing environment (Joëls \& Baram, 2009). 
Fear is an adaptive component of the acute stress response to potentially dangerous stimuli that threaten the integrity of the individual. However, when disproportionate in its intensity, chronic, irreversible and/or not associated with any actual risk, it constitutes a maladaptive response and may be symptomatic of anxiety-related neuropsychiatric disorders (Taber \& Hurley, 2009).

Anxiety disorders are marked by excessive fear (and avoidance), often in response to specific objects or situations, in the absence of true danger, and they are common in the general population (Shin \& Liberzon, 2010). As excessive fear is a key component of anxiety disorders, the search for the neurocircuitry of anxiety disorders has focused extensively on studies of fear circuits in animal models. These studies examined the neurocircuitry associated with fear responses in rats and mice using fear conditioning paradigms, inhibitory avoidance, and fear-potentiated startle models. The amygdala, PFC, and hippocampus have arisen as clear regions of interest in studies of anxiety disorders and are implicated in PTSD (Shin \& Liberzon, 2010).

The hippocampus is often implicated in the neurobiology of stress. Mineralocorticoid and glucocorticoid receptors are expressed in high numbers within the hippocampus. Although stress-induced corticosteroid signalling in the hippocampus has a beneficial role in regulating the time course of the HPA axis stress response (de Kloet et al., 2005), prolonged glucocorticoid signalling can damage the hippocampus as measured by dendritic atrophy, decreased neurogenesis, and deficits in synaptic plasticity (McEwen \& Gould, 1990; Sapolsky, 1996; McEwen, 1999; Meaney, 2001). In PTSD and major depression patients, hippocampus volumes are reduced (Bremner et al., 1995; Sheline et al., 1999; Woon \& Hedges, 2008), and smaller hippocampal volumes are predictive of vulnerability to develop stress-related disorders (Pitman et al., 2006).

The amygdala plays a role in the control of emotional and autonomic responses to stress. It is involved in mood regulation and in the mediation of fear and anxiety (Davis, 1992; LeDoux, 2007) and is bi-directionally related to the frontal cortex (McDonald, 1998) and hippocampus (Pitkanen et al., 2000). Studies of fear conditioning, pharmacologically induced fear, and responses to emotional stimuli and facial expressions have provided evidence that the human amygdala, although responsive to multiple salient stimuli, responds reliably and potentially preferably to stimuli that predict threat and can be involved in mediating fear/anxiety states. Given that patients with anxiety disorders experience fear and distress in response to possible predictors of threat, the amygdala has been hypothesized to be hyperresponsive in some anxiety disorders. According to some models, the amygdala is hyperresponsive in PTSD, which may account for exaggerated fear responses and the persistence of traumatic memories (Shin and Liberzon, 2010).

The PFC plays an integral role in mediating a range of executive functions that subserve the selection and processing of information necessary to plan, control and direct behaviour in a manner appropriate to current environmental demands (Goldman-Rakic, 1996; Rolls, 1996; Tremblay \& Schultz, 1999; Bush et al., 2000; Miller \& Cohen, 2001; Robbins, 2005). A growing literature from studies in laboratory animals demonstrates that the PFC not only plays a major role in orchestrating the behavioural and systemic response to stress, but that neurons in the rodent PFC are highly sensitive to stress and undergo significant remodelling following stress exposure. These findings support the notion that stress-induced alterations in PFC function represent a principle neural insult underlying deficits in executive function 
observed in stressed rodents, and the executive component of many neuropsychiatric diseases (for review see: Holmes \& Wellman, 2008).

The amygdala and hippocampus have well established roles in encoding and processing memory for emotional or stressful events into long term storage (Cahill et al., 1996; Canli et al., 2000; Richter-Levin \& Akirav, 2003; Joels et al., 2004; McGaugh, 2004; Phelps, 2004; Vianna et al., 2004; Diamond et al., 2005). However, stress effects on memory cannot be explained through only hippocampus and amygdala mediated alterations. There is growing interest in other brain areas, particularly the NAc, involved in mediating stress-related dysfunction (Willner et al., 1992; Zangen et al., 2001; Nestler et al., 2002). The NAc shell division may play an important role in integrating and consolidating representations of new experiences that are initially processed by both the amygdala and hippocampus (Seamans \& Phillips, 1994; Setlow et al., 2000; Reynolds \& Berridge, 2002). Anatomical findings demonstrate that the shell receives neural input from the BLA concerning the affective components of experiences (Mogenson et al., 1980; Petrovich et al., 1996), projections from the ventral subiculum region of the hippocampus regarding contextual features from the environment (Groenewegen et al., 1987; Meredith et al., 1990) and reward related components of learning experiences from the ventral tegmental area (Nauta et al., 1978).

\subsection{Role of the endocannabinoid system in unconditioned stress and anxiety}

Results from many studies indicate that the eCB system modulates unconditioned stressand anxiety-like responses (Viveros et al., 2005; Gorzalka et al., 2008; Lutz, 2009). A general conclusion that can be tentatively derived from the complicated and often contradictory literature is that inhibition of eCB signalling increases stress and anxiety, while moderate increases in eCB signalling decrease stress and anxiety (Lutz, 2009). The term "moderate" is used because strong stimulation of $\mathrm{eCB}$ signalling by high doses of CB1 receptor agonists potentiate stress- and anxiety-like responses (Rodriguez de Fonseca et al., 1996; Scherma et al., 2008; Lutz, 2009). This biphasic effect has been demonstrated in animal models of anxiety (Lafenetre et al., 2007; Hill \& Gorzalka, 2009), and also in humans. Cannabis may induce aversive states in some smokers, precipitating anxiety and panic attacks (Hall \& Solowij, 1998). Furthermore, THC administration may result in psychotic-like states (Linszen \& van Amelsvoort, 2007). These bidirectional effects of cannabinoids observed in humans can be mimicked in laboratory animals. Hence, in models predictive of anxiolytic-like activity, low doses of CB1 agonists tend to be anxiolytic and high doses tend to increase aversion and anxiety-related behaviours (Viveros et al., 2005).

Procedures used in studies on the role of eCBs in stress and anxiety evaluate the anxiolytic/anxiogenic effects of drugs by using standard tasks such as the elevated plus maze, social interaction, and defensive burying (Viveros et al., 2005; Lutz, 2009). Methods to modulate eCB signalling include genetic deletion of CB1 receptors, CB1 receptor antagonists (e.g., rimonobant/ SR141716, AM 251) and agonists (e.g., WIN55,212-2, HU210, which also activate CB2 receptors primarily found in the periphery (Freund et al., 2003; Di Marzo, 2008). Inhibitors of FAAH (URB597) or of the eCB transporter (AM404) have also been utilized, which leads to increased synaptic levels of anandamide and 2AG (Kathuria et al., 2003; Viveros et al., 2005; Bortolato et al., 2006).

Using the elevated plus maze, Patel \& Hillard (2006) found that cannabinoid receptor agonists WIN 55212-2 (0.3-10 mg/ kg) and CP 55,940 (0.001-0.3 mg/ kg) increase the time mice spend on the open arms (i.e. elicit an anxiolytic response) only at low doses. At the 
highest doses, both compounds alter overall locomotor activity. In contrast, THC (0.25-10 $\mathrm{mg} / \mathrm{kg}$ ) produces a dose-dependent reduction in time spent on open arms. The eCB uptake/catabolism inhibitor AM404 $(0.3-10 \mathrm{mg} / \mathrm{kg})$ produces an increase in time spent on the open arms at low doses and has no effect at the highest dose tested. The FAAH inhibitor URB597 (0.03-0.3 mg/ kg) produces a monophasic, dose-dependent increase in time spent on the open arms. The CB1 receptor antagonists SR141716 (1-10 mg/kg) and AM251 (1-10 $\mathrm{mg} / \mathrm{kg}$ ) produce dose-related decreases in time spent on open arms. Onaivi et al., (1990) have shown that THC induces increased aversion to the open arms of the elevated plus maze in both rats and mice that is similar to the aversion produced by anxiogenic agents. In contrast, mice treated with the agonists cannabidiol and nabilone spend a greater amount of time in the open arms of the maze, an effect similar to that produced by diazepam, the reference anxiolytic agent.

In the light-dark box, Berrendero \& Maldonado (2002) have shown that the administration of a low dose of THC $(0.3 \mathrm{mg} / \mathrm{kg})$ produces clear anxiolytic-like responses. The CB1 cannabinoid receptor antagonist, SR 141716A $(0.5 \mathrm{mg} / \mathrm{kg})$ completely blocks the anxiolyticlike response induced by THC, suggesting that this effect is mediated by CB1 cannabinoid receptors. In another study, systemic administration of the FAAH inhibitors URB597 and URB532 reduces anxiety-related behaviour in the rat elevated zero-maze and isolationinduced ultrasonic vocalisation tests (Kathuria et al., 2003). These effects are dose-dependent and blocked by the antagonist rimonabant. The FAAH inhibitor and eCB re-uptake inhibitor AM404 also exhibit a dose-dependent anxiolytic profile in the elevated plus-maze, defensive withdrawal test, and ultrasonic vocalisation test (Bortolato et al., 2006). URB597 has also been shown to be anxiolytic in the rat elevated plus-maze and open-field tests (Hill et al., 2007) and has recently been shown to reduce anxiety-related behaviour in the elevated plusmaze in Syrian hamsters (Moise et al., 2008).

Ribeiro et al. (2009) examined the dose-response effects of exogenous anandamide at doses of $0.01,0.1$, and $1.0 \mathrm{mg} / \mathrm{kg}$ in mice sequentially submitted to the open field and elevated plus-maze. Administered at $0.1 \mathrm{mg} / \mathrm{kg}$ (but not at 0.01 or $1 \mathrm{mg} / \mathrm{kg}$ ), anandamide increases the time spent and the distance covered in the central zone of the open field, as well as exploration of the open arms of the elevated plus-maze. Recently, Rubino 2008b demonstrated that the anxiolytic-like effect of a low anandamide dose is reversed by administration of the antagonist AM251, whereas the anxiogenic-like effect is inhibited by pre-treatment with capsazepine, a transient receptor potential vanilloid type 1 (TRPV1) receptor antagonist. The authors suggested that the anxiolytic effect evoked by anandamide might be due to the interaction with the CB1 cannabinoid receptor, whereas vanilloid receptors seem to be involved in the anxiogenic action of anandamide (Rubino 2008b). Marsch et al. (2007) reported that TRPV1 "null" mice exhibit a significantly reduced response to anxiogenic stimuli. Therefore, the anandamide-induced inverted U-shape pattern might be based on the fact that the intrinsic efficacy of anandamide on TRPV1 is relatively low compared to that observed on the CB1 receptor (Ross, 2003).

Transgenic mice deficient for FAAH, the enzyme that degrades anandamide, demonstrate reduced anxiety-like behaviour in the elevated plus maze and light-dark box compared with wild-type mice and these effects are prevented by systemic administration of the antagonist rimonabant (Moreira et al., 2008). On the other hand, transgenic mice lacking expression of the CB1 receptor demonstrate an anxiogenic profile in the elevated plus-maze, the light-dark box, open-field arena, and social interaction test (Maccarrone et al., 2002; Martin et al., 2002; Haller et al., 2002; 2004; Uriguen et al., 2004) and demonstrate impaired stress coping behaviour in the forced swim test (Steiner et al., 2008). Similarly, CB1 receptor antagonists 
increase anxiety-related behaviours in the elevated plus maze (Patel \& Hillard, 2006). Taken together, these studies suggest that $\mathrm{eCBs}$ act at CB1 receptors to reduce anxiety.

\subsection{Role of the endocannabinoid system in conditioned fear and anxiety}

Understanding the role of the $\mathrm{eCB}$ system in conditioned fear and aversive memories is important because a number of anxiety disorders, including PTSD and phobias, are thought to result from dysregulated fear neurocircuitry (Rauch et al., 2006). Conditioned fear is induced by pairing a neutral, conditioned stimulus (CS; e.g., a light, a tone, or a context) with an aversive stimulus (unconditioned stimulus, US; e.g., a mild footshock) that evokes a measurable fear response. Evoked fear responses have been used extensively in animal models to better understand the mechanisms by which aversive memories are formed, and to model diseases such as PTSD and specific phobia, where inciting cues lead to the production of pathological fear states.

Investigators have examined the effect of CB1 receptor agonists and antagonists on contextual and cue fear conditioning. Results from these studies were somewhat mixed. In rats, systemic injections of the CB1 receptor antagonist AM251 enhance both the acquisition and expression of cue fear conditioning (Arenos et al., 2006; Reich et al., 2008). Administering AM251 (5 mg/kg, i.p) during tone-footshock conditioning enhances acquisition of freezing behaviour for both trace fear conditioning (hippocampal-dependent) and delay fear conditioning (amygdala-dependent) (Reich et al., 2008). Recently, we used an inhibitory avoidance task and found that microinjecting AM251 (6 ng) into the BLA significantly enhances conditioned avoidance but has no effect on conditioning when microinjected into the hippocampal CA1 area (Ganon-Elazar \& Akirav, 2009; Abush \& Akirav, 2010). However, others have shown that mice lacking the CB1 receptor or systemically administered with the CB1 receptor antagonist AM251 (0.3-3 mg/kg) $30 \mathrm{~min}$ before behavioural testing show no contextually induced fear response (Mikics et al., 2006) and that the CB1 receptor antagonist rimonobant or genetic deletion of the CB1 receptor has no effect on the acquisition of cue and context fear conditioning in mice (Marsicano et al., 2002; Suzuki et al., 2004). On the other hand, cue-fear-potentiated startle is decreased by medial PFC injections of the CB1 receptor agonist WIN55212-2 or the FAAH inhibitor URB597 (Lin et al., 2008, 2009) and contextual fear conditioning is decreased by dorsolateral periaqueductal gray injections of either anandamide or the anandamide transport inhibitor AM404 (Resstel et al., 2008). Overall it appears that, as in the case of unconditioned fear, inhibition of eCB transmission increases fear while moderate stimulation of eCB transmission decreases fear.

\subsection{Role of the endocannabinoid system in extinction}

Extinction was established as a tool to treat conditioned fear by Freud in the 1920s. It has become widely accepted that a deficit in the capacity to extinguish memories of fear is at the root of fear disorders as a result of the distinction between those who do and do not develop serious symptoms after fearsome experiences, and the fact that fear disorders are treated with therapy based on extinction procedures. Moreover, panic attacks, phobias, and particularly PTSD are viewed by many as a deficit of extinction that should therefore be treated by an intensification of extinction (Charney et al., 1993; Wessa \& Flor, 2007; Milad et al., 2008). 
Experimental extinction learning occurs when a CS that previously predicted a US no longer does so, and over time, the conditioned response (e.g., freezing or elevated skin conductance responses) decreases. Extinction learning involves the ventromedial PFC, amygdala and hippocampus (Milad and Quirk, 2002; Phelps et al., 2004; Bouton et al., 2006). PTSD patients exhibit long-lasting reexperience of traumatic events and avoidance of the trauma-related stimuli, even though they recognize that the traumatic event is no longer occurring. It has been suggested that dysfunctional fear extinction plays an important role in the development of clinical symptoms, such as reexperiencing of trauma, in PTSD (Rothbaum et al., 2003; Quirk et al., 2006; Rauch et al., 2006; Milad et al., 2006). Furthermore, in a recent study, PTSD patients demonstrated deficient extinction recall as measured in skin conductance response in a 2-day fear conditioning and extinction procedure (Milad et al., 2008).

Clearly, animal models do not entirely mimic the complex features of psychiatric disorders. However, they can predict the clinical effects of substances and provide insights into the biological mechanisms of these diseases. Marsicano et al. (2002) found that CB1 receptordeficient mice show normal acquisition and consolidation in a fear conditioning task, but fear extinction is strongly impaired. Impaired extinction is also observed when the antagonist SR141716 is injected systemically into wild-type mice before the extinction trial, indicating that $\mathrm{CB} 1$ receptors are required at the moment of the extinction training. The findings that CB1 knockout mice exhibit impaired short- and long-term extinction of cueinduced conditioned fear responses have been replicated by other groups both for extinction of cue- or context-induced fear responses (Suzuki et al., 2004; Finn et al., 2004; Chhatwal et al., 2005; Lafenetre et al., 2007; Lutz, 2007; Niyuhire et al., 2007). We have recently shown that microinjecting the antagonist AM251 (6 ng) into the BLA or the CA1 significantly impairs extinction of inhibitory avoidance (Ganon-Elazar \& Akirav, 2009; Abush \& Akirav, 2010). Regarding the extinction of non-aversive memories, several studies suggested that the eCB system is not involved (Hölter et al., 2005; Niyuhire et al., 2007).

On the other hand, studies have demonstrated that pharmacological activation of eCB signalling promotes extinction of fear memories. For example, Chhatwal et al. (2005) found that systemic administration of AM404 $(10 \mathrm{mg} / \mathrm{kg})$ promotes extinction of conditioned fear using fear potentiated startle. This was replicated using systemic (Pamplona et al., 2008) and intracerebroventricular (Bitencourt et al., 2008) injections. In another study (Varvel et al., 2007), OL-135 (30 mg/ kg), an inhibitor of FAAH, enhanced the rate of extinction in a water maze task. Pamplona et al. (2006) showed that WIN 55-212,2 $(0.25 \mathrm{mg} / \mathrm{kg})$ facilitates the extinction of contextual fear in the fear conditioning task and of spatial memory in the water maze reversal task. We demonstrated that WIN 55,212-2 administered into the CA1 facilitates the extinction of inhibitory avoidance, with no effect on extinction kinetics when microinjected into the BLA (Ganon-Elazar \& Akirav, 2009; Abush \& Akirav, 2010).

Results of Marsicano et al. (2002) and subsequent investigations demonstrate that inhibition of eCB transmission robustly inhibits (or prolongs) fear extinction (Suzuki et al., 2004; Pamplona et al., 2006). Conversely, stimulation of eCB transmission accelerates fear extinction (Suzuki et al., 2004; Chhatwal et al., 2005; Barad et al., 2006; Abush \& Akirav, 2010). However, the role of $\mathrm{eCB}$ in the extinction of aversive memories is to some degree task-specific and negative results were reported (Kobilo et al., 2007; Lutz, 2007).

There is evidence to suggest that cannabinoids act on anxiety responses and fear learning through their effects on the amygdala. Central CB1 receptors are expressed at high levels in 
the lateral and basal nuclei of the amygdala (Katona et al., 2001), and extinction of aversive memories depends on cannabinoid receptors and signalling within the BLA (Marsicano et al., 2002; Kamprath et al., 2006;Laviolette and Grace 2006a). It has been demonstrated that activation of CB1 receptors attenuates anxiety responses and amygdala activation to aversive stimuli by modulating neuronal firing in the BLA (Pistis et al., 2004; Patel et al., 2005). We have demonstrated (Ganon-Elazar \& Akirav, 2009) that exposure to acute stress enhances conditioned avoidance and impairs inhibitory avoidance extinction. Intra-BLA WIN55,212-2 (5 $\mu \mathrm{g})$ prevents the stress-induced enhancement of conditioned avoidance as well as the stress-induced disruption of avoidance extinction (see Figure 1). This reversal effect was found to be associated with alterations in the HPA axis, as intra-BLA WIN55,2122 inhibits the stress-induced increase in plasma corticosterone levels (Ganon-Elazar and Akirav, 2009; see Figure 2). These findings support a possible therapeutic application for cannabinoids in the treatment of conditions associated with stress-related disorders and the inappropriate retention of aversive memories.

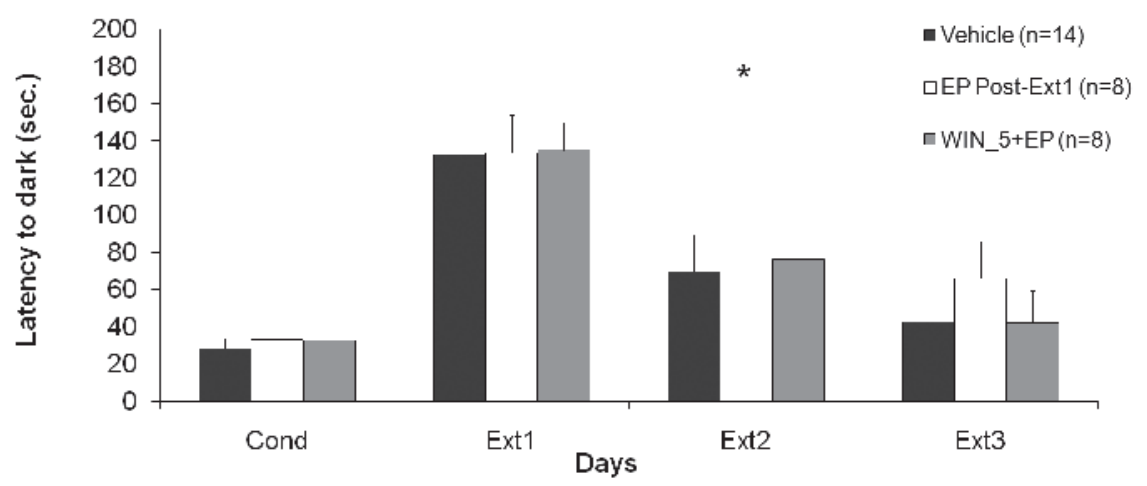

Fig. 1. Cannabinoid receptor agonist WIN55,212-2 (5 $\mu \mathrm{g} / 0.5 \mu \mathrm{l})$ blocks the effects of stress on inhibitory avoidance extinction

After the first extinction trial (Ext1), rats were microinjected with vehicle $(n=14)$, placed on the elevated platform (EP Post-Ext1, $n=8$ ) stress, or microinjected with WIN55,212-2 into the BLA and immediately afterward placed on the EP (WIN_5+EP, $n=8$ ). The EP Post-Ext1 group showed a significantly increased latency to enter the dark side on the second extinction day compared with the other groups (Ext2, p < 0.05). Thus, WIN55,212-2 administered into the BLA before stressor exposure prevents the disrupting effect of the stressor on IA extinction (data published by Ganon-Elazar and Akirav, 2009 in J Neurosci).

\subsection{Endocannabinoid system modulation of the hypothalamic-pituitary-adrenal axis (HPA) axis}

A body of evidence has emerged indicating a key role for the eCB system both in regulating basal HPA axis activity and in 'fine-tuning' the HPA axis response to stress (Finn, 2010). However, it should be borne in mind that elevation of eCB levels sometimes has effects that are different from those observed with exogenous cannabinoids, especially regarding eCB modulation of the HPA axis. 


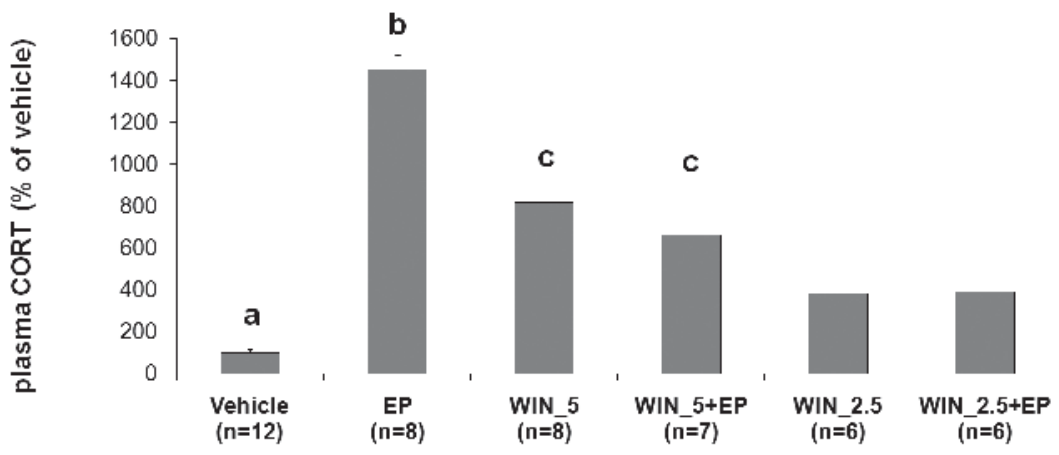

Fig. 2. The effects of the cannabinoid receptor agonist WIN55,212-2 and stress on corticosterone levels

Corticosterone levels were measured in rats microinjected with vehicle into the BLA (vehicle, $n=12)$, placed on the EP $(n=8)$, microinjected with WIN55,212-2 into the BLA (5 $\mu \mathrm{g} ;$ WIN_5, $n=8)$, microinjected with WIN55,212-2 into the BLA and placed on the EP (5 $\mu$ g; WIN_5+EP, $n=7)$, microinjected with a lower dose of WIN55,212-2 into the BLA (2.5 $\mu$ g; WIN_2.5, $n=6$ ), or microinjected with the lower dose of WIN55,212-2 and placed on the EP (WIN_2.5+EP, $n=6$ ). Data represent the means \pm SEM expressed as a percentage of the corticosterone values of the vehicle animals (corticosterone levels in the vehicle group, 95.52 $\pm 16.7 \mathrm{ng} / \mathrm{ml})(\mathrm{p}<0.05$, a: Vehicle group differs from all other groups; b: EP group differs from all other groups; c, differs from WIN_2.5 and WIN_2.5+EP groups) (data published by Ganon-Elazar and Akirav, 2009 in J Neurosci).

The HPA axis is the principal neuroendocrine component of the response to stress; during acute stress, corticotrophin releasing factor (CRF) is released into the portal system by neurons in the paraventricular nucleus (PVN). CRF induces release of adrenocorticotrophic hormone (ACTH) from the anterior pituitary. ACTH stimulates production of glucocorticoids (e.g., corticosterone in rats) in the adrenal gland. Glucocorticoids produce a range of effects on the cardiovascular, immune, metabolic, and neural systems that facilitate optimal responses to aversive stimuli (Pecoraro et al., 2006) but also exert potent negative feedback inhibition of the HPA axis glucocorticoids by inhibiting the release of CRF in the hypothalamus and ACTH in the pituitary. Hence, elevated circulating levels of glucocorticoids rapidly suppress HPA axis activity. Hypothalamic and extrahypothalamic limbic structures also regulate the HPA axis. The amygdala activates the HPA axis in response to stressful stimuli whereas the hippocampus and prefrontal cortex inhibit the HPA axis.

The relationship between stress and the eCB system is complex, and it has been reported that stressful events increase eCB levels in several brain areas, likely in response to the stimulation of glucocorticoid receptors (Di et al., 2005; Malcher-Lopes et al., 2006). Stress elicits the rapid formation of eCBs in the periaqueductal gray matter of the midbrain (Hohmann et al., 2005) and alters eCB content in the limbic forebrain, amygdala, striatum, and PFC Patel et al., 2005; Rademacher et al., 2008). Smoking marijuana in humans or administration of THC in animals stimulates ACTH and glucocorticoid secretion (Murphy et al., 1998; Manzanares et al., 1999). We found that intra-BLA administration of WIN 55,2122 increases corticosterone levels in naïve rats, but is able to reduce the stress-induced elevation in corticosterone levels (Ganon-Elazar \& Akirav, 2009). Similarly, Patel et al. (2004) 
have shown that mice treated systemically with the eCB transport inhibitor AM404 or the FAAH inhibitor URB597 show significantly decreased or eliminated restraint-induced corticosterone release. Studies have shown a decrease in the content of the endogenous cannabinoid ligand anandamide in the amygdala, through an increase in FAAH-mediated hydrolysis, in response to acute stress (Patel et al., 2005; Rademacher et al., 2008; Hill et al., 2009). Preventing this decline in amygdalar anandamide by local administration of a FAAH inhibitor into the BLA attenuates stress-induced activation of the HPA axis (Hill et al., 2009). Hence, the augmentation of eCB signalling can suppress stress-responsive systems (Patel et al., 2004; Cota, 2008; Steiner \& Wotjak, 2008). A low dose of CP55940 (0.03 mg/kg) suppresses stress-induced corticosterone release, whereas a high dose $(0.3 \mathrm{mg} / \mathrm{kg})$ facilitates corticosterone release in response to restraint, consistent with previous data that direct CB1 agonists have biphasic effects on HPA axis activation and anxiety-like behaviours. On the other hand, the absence of CB1 receptors in mice or the systemic administration of CB1 receptor antagonists results in enhanced stress-induced secretion of ACTH and corticosterone compared with wild-type controls (Manzanares et al., 1999; Barna et al., 2004; Haller et al., 2004; Patel et al., 2004; Steiner et al., 2008; Steiner \& Wotjak, 2008). For example, acute systemic administration of the antagonists SR141716 or AM251 to rodents results in increased circulating corticosterone levels (Patel et al., 2004; Wade et al., 2006; Steiner et al., 2008; Ganon-Elazar and Akirav, 2009). Basal plasma ACTH concentrations in response to novelty stress are increased in CB1 knock-out mice compared with wild-type animals (Haller et al., 2004), hence suggesting that eCB signalling negatively modulates HPA axis activity.

Taken together these findings demonstrate that the eCB system is an important regulator of the central stress response and that alterations of the $\mathrm{eCB}$ tone might be helpful in reducing the stress response and may be effective in preventing the occurrence of stress-related diseases.

There are several mechanisms by which cannabinoids may exert their anxiolytic effects via stress-related hormonal systems. The BLA is thought to process aversive sensory stimuli via afferent inputs to the central amygdala (CeA; LeDoux, 2000). It is also believed that GABAergic neurons in the intercalated nuclei serve as an intermediate relay station to generate feed forward inhibition of CeA after activation by BLA (Pare \& Smith, 1993). The effects of selective CB1 agonists on GABA-mediated inhibitory postsynaptic currents at lateral, but not central, amygdala nuclei may reduce inhibitory tone on BLA cells. Thus, CB1 agonists reduce GABA release in BLA interneurons, thereby reducing their inhibition of the GABAergic neurons of the intercalated nuclei, which, in turn, increases their inhibition of the pyramidal neurons of the CeA (Katona et al., 2001). Hence, the reduction in inhibitory tone may in turn indirectly reduce anxiety by enhancing the activity of intercalated GABAergic cells that inhibit activation of the CeA (Katona et al., 2001). In support, it has been shown that CB1 agonists decrease the excitability of projection neurons in the rat BLA (Pistis et al., 2004). In humans, the benzodiazepine, pro-GABAergic anxiolytic agent lorazepam has been shown to attenuate amygdala reactivity to threatening faces (Paulus et al., 2005). Another possibility is that cannabinoids decrease CRH levels in the CeA, and decreased CRH levels are associated with decreased aversive stress responses (Rodriguez de Fonseca et al., 1997). Clearly, CB1 receptor activation may also involve other neurochemical (serotonin, cholecystokinin, opioid, etc.) systems relevant to anxiety and fear behaviours (Viveros et al., 2005). 


\subsection{The endocannabinoid system in a brain circuit involved in stress and anxiety}

The eCB system participates in multiple brain circuits implicated in neuropsychiatric conditions, such as those modulating stress reactions, learning, extinction of fear, emotional regulation, and reward processes (e.g., the amygdala, hippocampus, NAc, and PFC). Neuroimaging studies have revealed that these structures are indeed active in individuals who smoked cannabis (Chang \& Chronicle, 2007). This notion is further supported by experiments detecting molecular correlates of neural activity in cannabinoid-treated laboratory animals. For example, THC causes c-fos expression in the amygdala and the NAc (McGregor et al., 1998) and a significant increase in cAMP response element-binding (CREB) activation in the PFC and hippocampus (Rubino et al., 2007).

Techniques based on intracranial injections of cannabinoids in rats revealed that activation of CB1 receptors, specifically in some of the structures mentioned above, is involved in inducing anxiolytic- or antidepressant-like effects (Bambico et al., 2007; Moreira et al., 2007; Rubino et al., 2008a, 2008b). For example, Rubino et al. (2008a) found that low doses of THC microinjected into the PFC $(10 \mu \mathrm{g})$ or ventral hippocampus $(5 \mu \mathrm{g})$ in rats induces an anxiolyticlike response during tests in the elevated plus-maze, while higher doses do not show an anxiolytic effect and even seem to switch into an anxiogenic profile. Similarly, low doses of the anandamide analogue, methanandamide $(0.1 \mu \mathrm{g})$, microinjected into the PFC, produce an anxiolytic-like response in rats, whereas higher doses $(10 \mu \mathrm{g})$ induce anxiety-like behaviours, as indicated by the number of entries onto and percentage of time spent on the open arm of a plus maze (Rubino et al., 2008b). Yet, other studies demonstrated that eCB activation in the amygdala and dorsal hippocampus results in an anxiogenic-like response. Low THC doses (1 $\mu \mathrm{g})$ in the BLA produce an anxiogenic-like response whereas higher doses are ineffective (Rubino et al., 2008a). WIN-55212-2 in the dorsal hippocampus (2.5 and $5 \mu \mathrm{g}$ ) produces a significant anxiogenic-like effect in rats that is reversed by AM251 (Roohbakhsh et al., 2007).

Local infusion of cannabinoid compounds into specific brain areas might be instrumental to identify neural pathways and neuroanatomically separated CB1 receptor subpopulations that may play distinct roles in and mediate the opposing actions of cannabinoids, notably, anxiolytic versus anxiogenic effects (Moreira et al., 2007; Viveros et al., 2007).

Although considerable evidence suggests that activation of CB1 receptors can induce learning and memory impairments (Sullivan, 2000; Robinson et al., 2003; O'Shea et al., 2004; Varvel et al., 2005), CB1 receptors are essential for the extinction of conditioned fear associations (Marsicano et al., 2002), indicating an important role for this receptor in neuronal emotional learning and memory. Laviolette and Grace 2006a demonstrated that CB1 receptors within the BLA-PFC circuit can potently modulate the magnitude of emotional associative learning processes during both the acquisition and expression of learned, emotionally salient conditioned associations. Using in vivo single-unit recordings in rats, they showed that the agonist WIN 55,212-2 potentiates the response of medial PFC neurons to olfactory cues paired previously with a footshock, whereas this associative responding is prevented by the antagonist AM251. In an olfactory fear-conditioning procedure, WIN 55,212-2 microinjected into the medial PFC enables behavioural responses to olfactory cues paired with a normally subthreshold footshock, whereas AM251 completely blocks emotional learning.

Treatment with cannabinoids significantly increases dopamine release in the NAc (Chen et al., 1990; Tanda et al., 1997). Yet, in situ hybridization and immunocytochemical studies reported a low-level, or even lack of CB1 receptors in the NAc, whereas other brain regions, 
such as the PFC, the hippocampus, and the amygdala, which densely innervate the NAc, show moderate to very high CB1 receptor levels (Mailleux and Vanderhaeghen, 1992; Matsuda et al., 1993; Tsou et al., 1998; Egertova and Elphick, 2000). It has been suggested that the BLA, hippocampus and PFC are likely candidates for conveying the indirect effects of cannabinoids on dopamine release within the NAc, thereby contributing to reward processes (Katona et al., 2001).

To summarize the role of the $\mathrm{eCB}$ system in stress, anxiety, and conditioned fear, there is a general consensus that the effects of cannabinoid agonists on anxiety seem to be biphasic, with low doses being anxiolytic and high doses being ineffective or possibly anxiogenic. There are several important characteristics of the $\mathrm{eCB}$ system that might explain these different effects of eCB modulation. First, in a physiological situation, eCB synthesis, and thus CB1 receptor activation, occurs in particular activated neuronal circuits. This is a notable difference from the situation following pharmacological treatment with receptor agonists, when the agent activates all CB1 receptors in the brain regardless of their specific involvement in a particular physiological process. Second, the CB1 receptor is expressed in diverse brain structures of relevance to psychiatric disorders and is mainly located presynaptically where it can suppress the release of other neurotransmitters (Marsicano \& Lutz, 1999; Mackie et al., 2005; Marsicano \& Lutz, 2006). These neurotransmitters include the main inhibitory neurotransmitter GABA, the main excitatory neurotransmitter glutamate, as well as acetylcholine, noradrenaline, and serotonin (Katona et al., 1999; Harkany et al., 2005; Monory et al., 2006; Oropeza et al., 2007; Häring et al., 2007). Thus, synthetic compounds delivered systemically lack both the spatial and temporal specificity of endogenous compounds (Viveros et al., 2007; Lafenetre et al., 2007; Moreira \& Lutz, 2008). This may explain not only the bell-shaped relationship between dose and effect that some studies have observed, but also why elevation of eCB levels sometimes has effects that are different from those observed with exogenous cannabinoids. Finally, the diversity of eCB ligands with their multiple synthetic and degradation pathways adds a further level of complexity to the eCB system (Di Marzo, 2008).

\section{The endocannabinoid system in human studies}

Cannabis can promote a relaxing and euphoric effect, thus relieving anxious states, or anxiety and panic attacks, depending on subjects and on the emotional state prior to use (Iversen, 2003). Other factors that affect the change in mood and anxiety-related responses are individual differences in absorption, the method of smoking, drug dose, previous history, anxiety level, and environmental context (Gonzalez, 2007; Moreira \& Lutz, 2008; Taber \& Hurley, 2009). Whilst variable, the effects of low doses are often described as rewarding, producing feelings of a "high", relaxation, reduced anxiety, and increased sociability (Hall \& Solowij, 1998; Murray et al., 2007). Human recreational cannabis users often report that low doses of the drug produce feelings of calmness and decreased anxiety (Abood and Martin, 1992; Porter and Felder, 2001). But high doses of THC modulate subjective anxiety (D'Souza et al., 2004). In any case, adverse reactions do occur (e.g., anxiety, panic, paranoia, psychotic symptoms), but are much less common than positive effects (Iversen, 2003; Kalant, 2004; Gonzalez, 2007). Functional imaging studies indicate that intoxication is associated with increased regional cerebral blood flow and metabolism, particularly in the frontal and limbic regions as well as the cerebellum (Gonzalez, 2007). 
Some studies support an influence of cannabis use on the development of psychiatric disorders, particularly schizophrenia and mood disorders (Iversen, 2003; Kalant, 2004; Leweke \& Koethe, 2008).

There is thus evidence that cannabis can have both anxiogenic and anxiolytic effects. These apparently conflicting observations may partly reflect the fact that Cannabis sativa contains multiple compounds that may have different psychoactive properties (Ashton, 2001). A recent study by Fusar-Poli et al., (2009) used functional magnetic resonance imaging (fMRI) to investigate the effects of the two main psychoactive constituents of Cannabis sativa, THC and cannabidiol, on the neural substrate of emotional processing. Cannabidiol and THC have distinct modulatory effects on the regional neural response to fearful faces. Cannabidiol attenuates the neurofunctional engagement of the amygdala and cingulate cortex when subjects view intensely fearful stimuli and this effect is correlated with a reduction in the electrodermal response, consistent with behavioural evidence that it has anxiolytic effects. In contrast, THC modulates activation in frontal and parietal areas and is associated with an increase in anxiety and the electrodermal response.

It is paradoxical that while individuals report reduced anxiety as the motivation for using cannabis, acute anxiety is the most common adverse effect of cannabis use, particularly at high doses (Crippa et al., 2009). Generally, acute anxiety following cannabis use is more common in drug-naïve subjects and when the drug is taken in novel or stressful environments. Cannabis use alone does not appear to be sufficient or necessary for the development of long-term anxiety but may be a risk factor that operates in conjunction with other vulnerability factors. Such factors include biological, neurodevelopmental, environmental and social influences, as well as personality traits or a combination of all of them (Lynskey et al., 2002; Windle \& Wiesner, 2004; Chabrol et al., 2005).

Although not first-choice medications, generally cannabinoids are well tolerated after oral administration (Moreira et al., 2009). Some aversive effects that may result from cannabis smoking, such as anxiety and panic, are rarely observed after oral administration of the agonists nabilone and THC (Martyn et al., 1995; Berlach et al., 2006; Skrabek et al., 2008). An fMRI study examined 16 healthy, recreational cannabis users after a double-blind crossover oral administration of THC or placebo. They found that THC significantly reduces amygdala reactivity to social signals of threat but does not affect activity in the primary visual and motor cortex (Phan et al., 2008). Moreover, it has been recently shown that the synthetic cannabinoid nabilone has beneficial effects in PTSD patients in regard to abolishing or greatly reducing nightmares that persisted in spite of treatment with conventional PTSD medications (Fraser, 2009). Hence, oral administration may help avoid the high peak serum concentration that occurs after cannabis smoking or intravenous administration (Moreira et al., 2009).

\section{Conclusions and future research directions}

The involvement of the eCB system in multiple aspects of brain function provides new targets for the development of novel therapeutic agents for a wide range of psychiatric disorders, including the treatment of anxiety disorders.

A major problem with using the $\mathrm{eCB}$ system as a potential therapeutic target is the fact that it has a complex role in mediating anxiety states. In essence, there is a problem of a narrow therapeutic window between the efficacy against selected symptoms that are of clinical significance and the unwanted risks. Further understanding the functioning of the eCB 
system should provide new therapeutic avenues that may avoid these psychiatric sideeffects. For example, in addition to receptor agonists, a number of compounds have been developed that prolong eCB action, either by inhibiting uptake or by decreasing hydrolysis (Grant \& Cahn, 2005; Pertwee, 2008). In particular, the specific FAAH inhibitor URB597 has anxiolytic-like properties without the sedative effects seen with cannabinoids, which directly activate CB1 receptors (Cota, 2008; Piomelli, 2008). Prolonging the activity of released anandamide using selective inhibitors of FAAH reduces anxiety indicating that this may be a therapeutically useful goal in the treatment of anxiety. Hence, modulation of neuronal endogenous cannabinoid signalling systems could represent a novel approach to the treatment of anxiety-related disorders while minimizing the adverse effects of direct action on cannabinoid receptor agonists.

\section{References}

Abood, M. E., \& Martin, B. R. (1992). Neurobiology of marijuana abuse. Trends in Pharmacological Sciences, 13, 201-206.

Abush, H., \& Akirav, I. Cannabinoids modulate hippocampal memory and plasticity. Hippocampus, 20(10), 1126-1138.

Akirav, I., \& Maroun, M. (2007). The role of the medial prefrontal cortex-amygdala circuit in stress effects on the extinction of fear. Neural Plasticity, 30873.

Andréasson, S., Engström, A., Allebeck, P., \& Rydberg, U. (1987). Cannabis and schizophrenia A longitudinal study of swedish conscripts. The Lancet, 330(8574), 1483-1486.

Arenos, J. D., Musty, R. E., \& Bucci, D. J. (2006). Blockade of cannabinoid CB1 receptors alters contextual learning and memory. European Journal of Pharmacology, 539(3), 177-183.

Ashton, C. H. (2001). Pharmacology and effects of cannabis: A brief review. The British Journal of Psychiatry, 178(2), 101.

Bambico, F. R., Katz, N., Debonnel, G., \& Gobbi, G. (2007). Cannabinoids elicit antidepressant-like behavior and activate serotonergic neurons through the medial prefrontal cortex. Journal of Neuroscience, 27(43), 11700-11711.

Barad, M., Gean, P. W., \& Lutz, B. (2006). The role of the amygdala in the extinction of conditioned fear. Biological Psychiatry, 60(4), 322-328.

Barna, I., Zelena, D., Arszovszki, A., \& Ledent, C. (2004). The role of endogenous cannabinoids in the hypothalamo-pituitary-adrenal axis regulation: In vivo and in vitro studies in CB1 receptor knockout mice. Life Sciences, 75(24), 2959-2970.

Berlach, D. M., Shir, Y., \& Ware, M. A. (2006). Experience with the synthetic cannabinoid nabilone in chronic noncancer pain. Pain Medicine, 7(1), 25-29.

Berrendero, F., \& Maldonado, R. (2002). Involvement of the opioid system in the anxiolyticlike effects induced by G9-tetrahydrocannabinol. Psychopharmacology-Berlin, 163(1), 111-117.

Bitencourt, R. M., Pamplona, F. A., \& Takahashi, R. N. (2008). Facilitation of contextual fear memory extinction and anti-anxiogenic effects of AM404 and cannabidiol in conditioned rats. European Neuropsychopharmacology, 18(12), 849-859.

Bortolato, M., Campolongo, P., Mangieri, R. A., Scattoni, M. L., Frau, R., Trezza, V., et al. (2006). Anxiolytic-like properties of the anandamide transport inhibitor AM404. Neuropsychopharmacology, 31(12), 2652-2659. 
Bouton, M. E., Westbrook, R. F., Corcoran, K. A., \& Maren, S. (2006). Contextual and temporal modulation of extinction: Behavioral and biological mechanisms. Biological Psychiatry, 60(4), 352-360.

Breivogel, C. S., \& Sim-Selley, L. J. (2009). Basic neuroanatomy and neuropharmacology of cannabinoids. International Review of Psychiatry, 21(2), 113-121.

Bremner, J. D., Randall, P., Scott, T. M., Bronen, R. A., Seibyl, J. P., Southwick, S. M., et al. (1995). MRI-based measurement of hippocampal volume in patients with combatrelated posttraumatic stress disorder. American Journal of Psychiatry, 152(7), 973-981.

Bush, G., Luu, P., \& Posner, M. I. (2000). Cognitive and emotional influences in anterior cingulate cortex. Trends in Cognitive Sciences, 4(6), 215-222.

Cahill, L., Haier, R. J., Fallon, J., Alkire, M. T., Tang, C., Keator, D., et al. (1996). Amygdala activity at encoding correlated with long-term, free recall of emotional information. Proceedings of the National Academy of Sciences of the United States of America, 93(15), 8016-8021.

Canli, T., Zhao, Z., Brewer, J., Gabrieli, J. D. E., \& Cahill, L. (2000). Event-related activation in the human amygdala associates with later memory for individual emotional experience. Journal of Neuroscience,20, RC99, 1-5.

Chabrol, H., Ducongé, E., Casas, C., Roura, C., \& Carey, K. B. (2005). Relations between cannabis use and dependence, motives for cannabis use and anxious, depressive and borderline symptomatology. Addictive Behaviors, 30(4), 829-840.

Chang, L., \& Chronicle, E. P. (2007). Functional imaging studies in cannabis users. The Neuroscientist, 13(5), 422-432.

Charney, D. S., Deutch, A. Y., Krystal, J. H., Southwick, S. M., \& Davis, M. (1993). Psychobiologic mechanisms of posttraumatic stress disorder. Archives of General Psychiatry, 50(4), 294-305.

Chen, J., Paredes, W., Li, J., Smith, D., Lowinson, J., \& Gardner, E. L. (1990). $\Delta$ 9tetrahydrocannabinol produces naloxone-blockable enhancement of presynaptic basal dopamine efflux in nucleus accumbens of conscious, freely-moving rats as measured by intracerebral microdialysis. Psychopharmacology, 102(2), 156-162.

Chhatwal, J. P., Myers, K. M., Ressler, K. J., \& Davis, M. (2005). Regulation of gephyrin and GABAA receptor binding within the amygdala after fear acquisition and extinction. Journal of Neuroscience, 25(2), 502-506.

Cota, D. (2008). The role of the endocannabinoid system in the regulation of hypothalamicpituitary-adrenal axis activity. Journal of Neuroendocrinology, 20(s1), 35-38.

Crippa, J. A., Zuardi, A. W., Martín-Santos, R., Bhattacharyya, S., Atakan, Z., McGuire, P., et al. (2009). Cannabis and anxiety: A critical review of the evidence. Human Psychopharmacology: Clinical and Experimental, 24(7), 515-523.

Davidson, J. R. (2000). Pharmacotherapy of posttraumatic stress disorder: Treatment options, long-term follow-up, and predictors of outcome. The Journal of Clinical Psychiatry, 5, 52-61.

Davis, M. (1992). The role of the amygdala in fear and anxiety. Annual Review of Neuroscience, 15(1), 353-375.

De Kloet, E. R., Joëls, M., \& Holsboer, F. (2005). Stress and the brain: From adaptation to disease. Nature Reviews Neuroscience, 6(6), 463-475. 
Devane, W. A., Dysarz, F. A., Johnson, M. R., Melvin, L. S., \& Howlett, A. C. (1988). Determination and characterization of a cannabinoid receptor in rat brain. Molecular Pharmacology, 34(5), 605-613.

Devane, W. A., Hanus, L., Breuer, A., Pertwee, R. G., Stevenson, L. A., Griffin, G., et al. (1992). Isolation and structure of a brain constituent that binds to the cannabinoid receptor. Science, 258(5090), 1946-1949.

Di, S., Malcher-Lopes, R., Marcheselli, V. L., Bazan, N. G., \& Tasker, J. G. (2005). Rapid glucocorticoid-mediated endocannabinoid release and opposing regulation of glutamate and \{gamma\}-aminobutyric acid inputs to hypothalamic magnocellular neurons. Endocrinology, 146(10), 4292-4301.

Diagnostic and Statistical Manual of Mental Disorders (1994). 4th ed. American Psychiatric Association Washington, DC: American Psychiatric Association.

Diamond, D. M., Park, C. R., Campbell, A. M., \& Woodson, J. C. (2005). Competitive interactions between endogenous LTD and LTP in the hippocampus underlie the storage of emotional memories and stress-induced amnesia. Hippocampus, 15(8), 1006-1025.

Di Marzo, V. (2008). Endocannabinoids: Synthesis and degradation. Reviews of Physiology Biochemistry and Pharmacology,160,1-24.

D'Souza, D. C., Perry, E., MacDougall, L., Ammerman, Y., Cooper, T., Wu, Y., et al. (2004). The psychotomimetic effects of intravenous delta-9-tetrahydrocannabinol in healthy individuals: Implications for psychosis. Neuropsychopharmacology, 29(8), 1558-1572.

Egertová, M., \& Elphick, M. R. (2000). Localisation of cannabinoid receptors in the rat brain using antibodies to the intracellular C-terminal tail of CB1. The Journal of Comparative Neurology, 422(2), 159-171.

Emrich, H. M., Leweke, F. M., \& Schneider, U. (1997). Towards a cannabinoid hypothesis of schizophrenia: Cognitive impairments due to dysregulation of the endogenous cannabinoid system. Pharmacology Biochemistry and Behavior, 56(4), 803-807.

Finn, D., Beckett, S., Richardson, D., Kendall, D., Marsden, C., \& Chapman, V. (2004). Evidence for differential modulation of conditioned aversion and fear-conditioned analgesia by CB1 receptors. European Journal of Neuroscience, 20(3), 848-852.

Finn, D.P. (2010). Endocannabinoid-mediated modulation of stress responses: physiological and pathophysiological significance. Immunobiology,215(8), 629-46.

Fraser, G. A. (2009). The use of a synthetic cannabinoid in the management of Treatment-Resistant nightmares in posttraumatic stress disorder (PTSD). CNS Neuroscience \& Therapeutics, 15(1), 84-88.

Freund, T. F., Katona, I., \& Piomelli, D. (2003). Role of endogenous cannabinoids in synaptic signaling. Physiological Reviews, 83(3), 1017-1066.

Fusar-Poli, P., Crippa, J. A., Bhattacharyya, S., Borgwardt, S. J., Allen, P., Martin-Santos, R., et al. (2009). Distinct effects of \{delta\} 9-tetrahydrocannabinol and cannabidiol on neural activation during emotional processing. Archives of General Psychiatry, 66(1), 95-105.

Ganon-Elazar, E., \& Akirav, I. (2009). Cannabinoid receptor activation in the basolateral amygdala blocks the effects of stress on the conditioning and extinction of inhibitory avoidance. Journal of Neuroscience, 29(36), 11078-11088. 
Gaoni, Y., \& Mechoulam, R. (1964). Isolation, structure, and partial synthesis of an active constituent of hashish. Journal of the American Chemical Society, 86(8), 1646-1647.

Goldman-Rakic, P. S., Cools, A., \& Srivastava, K. (1996). The prefrontal landscape: Implications of functional architecture for understanding human mentation and the central executive [and discussion]. Philosophical Transactions: Biological Sciences, 351(1346), 1445-1453.

Gong, J. P., Onaivi, E. S., Ishiguro, H., Liu, Q. R., Tagliaferro, P. A., Brusco, A., et al. (2006). Cannabinoid CB2 receptors: Immunohistochemical localization in rat brain. Brain Research, 1071(1), 10-23.

Gonzalez, R. (2007). Acute and non-acute effects of cannabis on brain functioning and neuropsychological performance. Neuropsychology Review, 17(3), 347-361.

Gorzalka, B. B., Hill, M. N., \& Hillard, C. J. (2008). Regulation of endocannabinoid signaling by stress: Implications for stress-related affective disorders. Neuroscience $\mathcal{E}$ Biobehavioral Reviews, 32(6), 1152-1160.

Grant, I., \& Cahn, B. R. (2005). Cannabis and endocannabinoid modulators: Therapeutic promises and challenges. Clinical Neuroscience Research, 5(2-4), 185-199.

Groenewegen, H., der Zee, E., Te Kortschot, A., \& Witter, M. (1987). Organization of the projections from the subiculum to the ventral striatum in the rat. A study using anterograde transport of phaseolus vulgaris leucoagglutinin. Neuroscience, 23(1), 103-120.

Hall, W., \& Solowij, N. (1998). Adverse effects of cannabis. The Lancet, 352(9140), 1611-1616.

Hall, W., \& Degenhardt, L. (2000). Cannabis use and psychosis: A review of clinical and epidemiological evidence. Australian and New Zealand Journal of Psychiatry, 34(1), 2634.

Haller, J., Bakos, N., Szirmay, M., Ledent, C., \& Freund, T. (2002). The effects of genetic and pharmacological blockade of the CB1 cannabinoid receptor on anxiety. European Journal of Neuroscience, 16(7), 1395-1398.

Haller, J., Varga, B., Ledent, C., Barna, I., \& Freund, T. (2004). Context-dependent effects of CB1 cannabinoid gene disruption on anxiety-like and social behaviour in mice. European Journal of Neuroscience, 19(7), 1906-1912.

Häring, M., Marsicano, G., Lutz, B., \& Monory, K. (2007). Identification of the cannabinoid receptor type 1 in serotonergic cells of raphe nuclei in mice. Neuroscience, 146(3), 1212-1219.

Harkany, T., Dobszay, M., Cayetanot, F., Härtig, W., Siegemund, T., Aujard, F., et al. (2005). Redistribution of CB1 cannabinoid receptors during evolution of cholinergic basal forebrain territories and their cortical projection areas: A comparison between the gray mouse lemur (microcebus murinus, primates) and rat. Neuroscience, 135(2), 595-609.

Herkenham, M., Lynn, A. B., Johnson, M. R., Melvin, L. S., de Costa, B. R., \& Rice, K. C. (1991). Characterization and localization of cannabinoid receptors in rat brain: A quantitative in vitro autoradiographic study. Journal of Neuroscience, 11(2), 563-583.

Hill, M. N., \& Gorzalka, B. B. (2009). The endocannabinoid system and the treatment of mood and anxiety disorders. CNS \& Neurological Disorders-Drug Targets (Formerly Current Drug Targets), 8(6), 451-458. 
Hill, M. N., Karacabeyli, E. S., \& Gorzalka, B. B. (2007). Estrogen recruits the endocannabinoid system to modulate emotionality. Psychoneuroendocrinology, 32(4), 350-357.

Hill, M. N., McLaughlin, R. J., Morrish, A. C., Viau, V., Floresco, S. B., Hillard, C. J., et al. (2009). Suppression of amygdalar endocannabinoid signaling by stress contributes to activation of the Hypothalamic-Pituitary-Adrenal axis. Neuropsychopharmacology, 34(13), 2733-2745.

Hohmann, A. G., Suplita, R. L., Bolton, N. M., Neely, M. H., Fegley, D., Mangieri, R., et al. (2005). An endocannabinoid mechanism for stress-induced analgesia. Nature, 435(7045), 1108-1112.

Holmes, A., \& Wellman, C. L. (2009). Stress-induced prefrontal reorganization and executive dysfunction in rodents. Neuroscience \& Biobehavioral Reviews, 33(6), 773-783.

Hölter, S. M., Kallnik, M., Wurst, W., Marsicano, G., Lutz, B., \& Wotjak, C. T. (2005). Cannabinoid CB1 receptor is dispensable for memory extinction in an appetitivelymotivated learning task. European Journal of Pharmacology, 510(1-2), 69-74.

Howlett, A. C., Bidaut-Russell, M., Devane, W. A., Melvin, L. S., Johnson, M. R., \& Herkenham, M. (1990). The cannabinoid receptor: Biochemical, anatomical and behavioral characterization. Trends in Neurosciences, 13(10), 420-423.

Iversen, L. (2003). Cannabis and the brain. Brain, 126(6), 1252-1270.

Jankord, R., \& Herman, J. P. (2008). Limbic regulation of Hypothalamo-Pituitary-Adrenocortical function during acute and chronic stress. Annals of the New York Academy of Sciences, 1148(1), 64-73.

Joels, M., Karst, H., Alfarez, D., Heine, V. M., Qin, Y., Riel, E., et al. (2004). Effects of chronic stress on structure and cell function in rat hippocampus and hypothalamus. Stress: The International Journal on the Biology of Stress, 7(4), 221-231.

Joëls, M., \& Baram T.Z. (2009). The neuro-symphony of stress. Nature Review Neuroscience, 10(6), 459-66.

Johns, A. (2001). Psychiatric effects of cannabis. The British Journal of Psychiatry, 178(2), 116.

Kalant, H. (2004). Adverse effects of cannabis on health: An update of the literature since 1996. Progress in Neuro-Psychopharmacology and Biological Psychiatry, 28(5), 849-863.

Kamprath, K., Marsicano, G., Tang, J., Monory, K., Bisogno, T., Marzo, V. D., et al. (2006). Cannabinoid CB1 receptor mediates fear extinction via habituation-like processes. Journal of Neuroscience, 26(25), 6677-6686.

Kathuria et al., 2003. Modulation of anxiety through blockade of anandamide hydrolysis. Nature Medicine, 9(1), 76-81.

Katona, I., Rancz, E. A., Acsady, L., Ledent, C., Mackie, K., Hajos, N., et al. (2001). Distribution of CB1 cannabinoid receptors in the amygdala and their role in the control of GABAergic transmission. Journal of Neuroscience, 21(23), 9506-9518.

Katona, I., Sperlagh, B., Sik, A., Kafalvi, A., Vizi, E. S., Mackie, K., et al. (1999). Presynaptically located CB1 cannabinoid receptors regulate GABA release from axon terminals of specific hippocampal interneurons. Journal of Neuroscience, 19(11), 4544-4558.

Kessler, R. C., Sonnega, A., Bromet, E., Hughes, M., \& Nelson, C. B. (1995). Posttraumatic stress disorder in the national comorbidity survey. Archives of General Psychiatry, 52(12), 1048-1060. 
Kobilo, T., Hazvi, S., \& Dudai, Y. (2007). Role of cortical cannabinoid CB1 receptor in conditioned taste aversion memory. European Journal of Neuroscience, 25(11), 34173421.

Kogan, N., \& Mechoulam, R. (2006). The chemistry of endocannabinoids. Journal of Endocrinological Investigation, 29(3), 3-14.

Lafenętre, P., Chaouloff, F., \& Marsicano, G. (2007). The endocannabinoid system in the processing of anxiety and fear and how CB1 receptors may modulate fear extinction. Pharmacological Research, 56(5), 367-381.

Laviolette and Grace 2006a. Cannabinoids potentiate emotional learning plasticity in neurons of the medial prefrontal cortex through basolateral amygdala inputs. Journal of Neuroscience, 26(24), 6458-6468.

Laviolette and Grace 2006b. The roles of cannabinoid and dopamine receptor systems in neural emotional learning circuits: Implications for schizophrenia and addiction. Cellular and Molecular Life Sciences, 63(14), 1597-1613.

LeDoux, J. E. (2000). Emotion circuits in the brain. Annual Review of Neuroscience, 23, 155-184.

LeDoux, J. (2007). The amygdala. Current Biology: CB, 17(20), R868-874.

Leweke, F. M., \& Koethe, D. (2008). Cannabis and psychiatric disorders: It is not only addiction. Addiction Biology, 13(2), 264-275.

Lin, H. C., Mao, S. C., Chen, P. S., \& Gean, P. W. (2008). Chronic cannabinoid administration in vivo compromises extinction of fear memory. Learning $\mathcal{E}$ Memory, 15(12), 876884.

Lin, H. C., Mao, S. C., Su, C. L., \& Gean, P. W. (2009). The role of prefrontal cortex CB1 receptors in the modulation of fear memory. Cerebral Cortex, 19(1), 165-175.

Linszen, D., \& van Amelsvoort, T. (2007). Cannabis and psychosis: an update on course and biological plausible mechanisms. Current Opinion in Psychiatry, 20(2), 116-20.

Lutz, B. (2007). The endocannabinoid system and extinction learning. Molecular Neurobiology, 36(1), 92-101.

Lutz, B. (2009). Endocannabinoid signals in the control of emotion. Current Opinion in Pharmacology, 9(1), 46-52.

Lynskey, M., Heath, A., Nelson, E., Bucholz, K., Madden, P., Slutske, W., et al. (2002). Genetic and environmental contributions to cannabis dependence in a national young adult twin sample. Psychological Medicine, 32(02), 195-207.

Maccarrone, M., Valverde, O., Barbaccia, M. L., Castañé, A., Maldonado, R., Ledent, C., et al. (2002). Age-related changes of anandamide metabolism in CB1 cannabinoid receptor knockout mice: Correlation with behaviour. European Journal of Neuroscience, 15(7), 1178-1186.

Mackie, K. (2005). Distribution of cannabinoid receptors in the central and peripheral nervous system. Cannabinoids,168, 299-325.

Mailleux, P., \& Vanderhaeghen, J. J. (1992). Distribution of neuronal cannabinoid receptor in the adult rat brain: A comparative receptor binding radioautography and in situ hybridization histochemistry. Neuroscience, 48(3), 655-668.

Malcher-Lopes, R., Di, S., Marcheselli, V. S., Weng, F. J., Stuart, C. T., Bazan, N. G., et al. (2006). Opposing crosstalk between leptin and glucocorticoids rapidly modulates synaptic excitation via endocannabinoid release. Journal of Neuroscience, 26(24), 6643-6650. 
Manzanares, J., Corchero, J., \& Fuentes, J. A. (1999). Opioid and cannabinoid receptormediated regulation of the increase in adrenocorticotropin hormone and corticosterone plasma concentrations induced by central administration of [delta] 9tetrahydrocannabinol in rats. Brain Research, 839(1), 173-179.

Marsch, R., Foeller, E., Rammes, G., Bunck, M., Kossl, M., Holsboer, F., et al. (2007). Reduced anxiety, conditioned fear, and hippocampal long-term potentiation in transient receptor potential vanilloid type 1 receptor-deficient mice. Journal of Neuroscience, $27(4), 832-839$.

Marsicano, G., \& Lutz, B. (1999). Expression of the cannabinoid receptor CB1 in distinct neuronal subpopulations in the adult mouse forebrain. European Journal of Neuroscience, 11(12), 4213-4225.

Marsicano, G., \& Lutz, B. (2006). Neuromodulatory functions of the endocannabinoid system. Journal of Endocrinological Investigation, 29(3), 27-46.

Marsicano, G., Wotjak, C. T., Azad, S. C., Bisogno, T., Rammes, G., Cascio, M. G., et al. (2002). The endogenous cannabinoid system controls extinction of aversive memories. Nature, 418(6897), 530-534.

Martin, M., Ledent, C., Parmentier, M., Maldonado, R., \& Valverde, O. (2002). Involvement of CB1 cannabinoid receptors in emotional behaviour. Psychopharmacology, 159(4), 379-387.

Martyn, C. N., Illis, L. S., \& Thom, J. (1995). Nabilone in the treatment of multiple sclerosis. Lancet, 345(8949), 579.

Mathers, D., \& Ghodse, A. (1992). Cannabis and psychotic illness. The British Journal of Psychiatry, 161(5), 648-653.

Matsuda, L. A., Bonner, T. I., \& Lolait, S. J. (1993). Localization of cannabinoid receptor mRNA in rat brain. The Journal of Comparative Neurology, 327(4), 535-550.

McDonald, A. J. (1998). Cortical pathways to the mammalian amygdala. Progress in Neurobiology, 55(3), 257-332.

McGregor, I. S., Arnold, J. C., Weber, M. F., Topple, A. N., \& Hunt, G. E. (1998). A comparison of [delta] 9-THC and anandamide induced c-fos expression in the rat forebrain. Brain Research, 802(1-2), 19-26.

McEwen, B. S. (1999). Stress and hippocampal plasticity. Annual Review of Neuroscience, 22(1), 105-122.

McEwen, B. C., and E. gould (1990) adrenal steroid influences on the survival of hippocampal neurons. Biochem.Pharmacol, 40, 2393-2402.

McGaugh, J. L. (2004). The amygdala modulates the consolidation of memories of emotionally arousing experiences. Annu.Rev.Neurosci., 27, 1-28.

Meaney, M. J. (2001). Maternal care, gene expression, and the transmission of individual differences in stress reactivity across generations. Neuroscience, 24, 1161-1192.

Meredith, G., Wouterlood, F., \& Pattiselanno, A. (1990). Hippocampal fibers make synaptic contacts with glutamate decar $\square$ ylase-immunoreactive neurons in the rat nucleus accumbens. Brain Research, 513(2), 329-334.

Mikics, É., Dombi, T., Barsvári, B., Varga, B., Ledent, C., Freund, T. F., et al. (2006). The effects of cannabinoids on contextual conditioned fear in CB1 knockout and CD1 mice. Behavioural Pharmacology, 17(3), 223-230. 
Milad, M.R., Orr, S.P., Lasko, N.B., Chang, Y., Rauch, S.L., Pitman, RK. (2008). Presence and acquired origin of reduced recall for fear extinction in PTSD: results of a twin study. Journal of Psychiatric Research, 42(7), 515-20.

Milad, M. R., \& Quirk, G. J. (2002). Neurons in medial prefrontal cortex signal memory for fear extinction. Nature, 420(6911), 70-74.

Milad, M. R., Rauch, S. L., Pitman, R. K., \& Quirk, G. J. (2006). Fear extinction in rats: Implications for human brain imaging and anxiety disorders. Biological Psychology, 73(1), 61-71.

Miller, E. K., \& Cohen, J. D. (2001). An integrative theory of prefrontal cortex function. Annual Review of Neuroscience, 24(1), 167-202.

Mogenson, G. J., Jones, D. L., \& Yim, C. Y. (1980). From motivation to action: Functional interface between the limbic system and the motor system. Progress in Neurobiology, 14(2-3), 69-97.

Moise, A. M., Eisenstein, S. A., Astarita, G., Piomelli, D., \& Hohmann, A. G. (2008). An endocannabinoid signaling system modulates anxiety-like behavior in male syrian hamsters. Psychopharmacology, 200(3), 333-346.

Monory, K., Massa, F., Egertová, M., Eder, M., Blaudzun, H., Westenbroek, R., et al. (2006). The endocannabinoid system controls key epileptogenic circuits in the hippocampus. Neuron, 51(4), 455-466.

Moreira, F. A., Aguiar, D. C., \& Guimarães, F. S. (2007). Anxiolytic-like effect of cannabinoids injected into the rat dorsolateral periaqueductal gray. Neuropharmacology, 52(3), 958-965.

Moreira, F. A., Grieb, M., \& Lutz, B. (2009). Central side-effects of therapies based on CB1 cannabinoid receptor agonists and antagonists: Focus on anxiety and depression. Best Practice E Research Clinical Endocrinology E Metabolism, 23(1), 133-144.

Moreira, F. A., Kaiser, N., Monory, K., \& Lutz, B. (2008). Reduced anxiety-like behaviour induced by genetic and pharmacological inhibition of the endocannabinoiddegrading enzyme fatty acid amide hydrolase (FAAH) is mediated by CB1 receptors. Neuropharmacology, 54(1), 141-150.

Moreira, F. A., \& Lutz, B. (2008). The endocannabinoid system: Emotion, learning and addiction. Addiction Biology, 13(2), 196-212.

Murphy, L. L., Muñoz, R. M., Adrian, B. A., \& Villanúa, M. A. (1998). Function of cannabinoid receptors in the neuroendocrine regulation of hormone secretion* 1 . Neurobiology of Disease, 5(6), 432-446.

Murray, R. M., Morrison, P. D., Henquet, C., \& Di Forti, M. (2007). Cannabis, the mind and society: The hash realities. Nature Reviews Neuroscience, 8(11), 885-895.

Nauta, W., Smith, G., Faull, R., \& Domesick, V. B. (1978). Efferent connections and nigral afferents of the nucleus accumbens septi in the rat. Neuroscience, 3(4-5), 385-401.

Nestler, E. J., Barrot, M., DiLeone, R. J., Eisch, A. J., Gold, S. J., \& Monteggia, L. M. (2002). Neurobiology of depression. Neuron, 34(1), 13-25.

Niyuhire, F., Varvel, S. A., Thorpe, A. J., Stokes, R. J., Wiley, J. L., \& Lichtman, A. H. (2007). The disruptive effects of the $\mathrm{CB} 1$ receptor antagonist rimonabant on extinction learning in mice are task-specific. Psychopharmacology, 191(2), 223-231.

O'Shea, M., Singh, M. E., McGregor, I. S., \& Mallet, P. E. (2004). Chronic cannabinoid exposure produces lasting memory impairment and increased anxiety in adolescent but not adult rats. Journal of Psychopharmacology, 18(4), 502-508. 
Onaivi, E., Green, M., \& Martin, B. (1990). Pharmacological characterization of cannabinoids in the elevated plus maze. Journal of Pharmacology and Experimental Therapeutics, 253(3), 1002-1009.

Onaivi, E. S., Ishiguro, H., Sejal, P., Meozzi, P. A., Myers, L., Tagliaferro, P., et al. (2006). Methods to study the behavioral effects and expression of $\mathrm{CB} \sim 2$ cannabinoid receptors and its gene transcripts in chronic mild stress model of depression. Methods in Molecular Medicine, 123, 291-298.

Oropeza, V. C., Mackie, K., \& Van Bockstaele, E. J. (2007). Cannabinoid receptors are localized to noradrenergic axon terminals in the rat frontal cortex. Brain Research, 1127, 36-44.

Orr, S. P., Pitman, R. K., Lasko, N. B., \& Herz, L. R. (1993). Psychophysiological assessment of posttraumatic stress disorder imagery in world war II and korean combat veterans. Journal of Abnormal Psychology, 102(1), 152-159.

Pamplona, F. A., Bitencourt, R. M., \& Takahashi, R. N. (2008). Short-and long-term effects of cannabinoids on the extinction of contextual fear memory in rats. Neurobiology of Learning and Memory, 90(1), 290-293.

Pamplona, F. A., Prediger, R. D. S., Pandolfo, P., \& Takahashi, R. N. (2006). The cannabinoid receptor agonist WIN 55,212-2 facilitates the extinction of contextual fear memory and spatial memory in rats. Psychopharmacology, 188(4), 641-649.

Pare, D., \& Smith, Y. (1993). The intercalated cell masses project to the central and medial nuclei of the amygdala in cats. Neuroscience, 57(4), 1077-1090.

Parolaro, D., Realini, N., Vigano, D., Guidali, C., \& Rubino, T. (2010). The endocannabinoid system and psychiatric disorders. Experimental Neurology, 224(1), 3-14.

Patel, S., Cravatt, B. F., \& Hillard, C. J. (2004). Synergistic interactions between cannabinoids and environmental stress in the activation of the central amygdala. Neuropsychopharmacology, 30(3), 497-507.

Patel, S., \& Hillard, C. J. (2006). Pharmacological evaluation of cannabinoid receptor ligands in a mouse model of anxiety: Further evidence for an anxiolytic role for endogenous cannabinoid signaling. Journal of Pharmacology and Experimental Therapeutics, 318(1), 304-311.

Patel, S., Roelke, C. T., Rademacher, D. J., Cullinan, W. E., \& Hillard, C. J. (2004). Endocannabinoid signaling negatively modulates stress-induced activation of the hypothalamic-pituitary-adrenal axis. Endocrinology, 145(12), 5431-5438.

Patel, S., Roelke, C. T., Rademacher, D. J., \& Hillard, C. J. (2005). Inhibition of restraint stressinduced neural and behavioural activation by endogenous cannabinoid signalling. European Journal of Neuroscience, 21(4), 1057-1069.

Patton, G. C., Coffey, C., Carlin, J. B., Degenhardt, L., Lynskey, M., \& Hall, W. (2002). Cannabis use and mental health in young people: Cohort study. Bmj, 325(7374), 1195-1198.

Paulus, M. P., Feinstein, J. S., Castillo, G., Simmons, A. N., \& Stein, M. B. (2005). Dosedependent decrease of activation in bilateral amygdala and insula by lorazepam during emotion processing. Archives of General Psychiatry, 62(3), 282-288.

Pazos, M. R., Benito, C., Tolón, R. M., \& Romero, J. (2005). Functional neuroanatomy of the endocannabinoid system. Pharmacology Biochemistry and Behavior, 81(2), 239-247. 
Pecoraro, N., Dallman, M. F., Warne, J. P., Ginsberg, A. B., Laugero, K. D., la Fleur, S. E., et al. (2006). From malthus to motive: How the HPA axis engineers the phenotype, yoking needs to wants. Progress in Neurobiology, 79(5-6), 247-340.

Pertwee, R. G. (2008). Ligands that target cannabinoid receptors in the brain: From THC to anandamide and beyond. Addiction Biology, 13(2), 147-159.

Petrovich, G., Risold, P., \& Swanson, L. (1996). Organization of projections from the basomedial nucleus of the amygdala: A PHAL study in the rat. The Journal of Comparative Neurology, 374(3), 387-420.

Phan, K. L., Angstadt, M., Golden, J., Onyewuenyi, I., Popovska, A., \& de Wit, H. (2008). Cannabinoid modulation of amygdala reactivity to social signals of threat in humans. Journal of Neuroscience, 28(10), 2313-2319.

Phelps, E. A. (2004). Human emotion and memory: Interactions of the amygdala and hippocampal complex. Current Opinion in Neurobiology, 14(2), 198-202.

Phelps, E. A., Delgado, M. R., Nearing, K. I., \& LeDoux, J. E. (2004). Extinction learning in humans:: Role of the amygdala and vmPFC. Neuron, 43(6), 897-905.

Piomelli, D. (2003). The molecular logic of endocannabinoid signalling. Nature Reviews Neuroscience, 4(11), 873-884.

Piomelli, D. (2008). Bedside to bench: The element of surprise. Nature Medicine, 14(7), 720721.

Pistis, M., Perra, S., Pillolla, G., Melis, M., Gessa, G. L., \& Muntoni, A. L. (2004). Cannabinoids modulate neuronal firing in the rat basolateral amygdala: Evidence for CB1-and non-CB1-mediated actions. Neuropharmacology, 46(1), 115-125.

Pitkänen, A., Pikkarainen, M., Nurminen, N., \& Ylinen, A. (2000). Reciprocal connections between the amygdala and the hippocampal formation, perirhinal cortex, and postrhinal cortex in rat: A review. Annals of the New York Academy of Sciences, 911(1), 369-391.

Pitman, R. K., Gilbertson, M. W., Gurvits, T. V., May, F. S., Lasko, N. B., Metzger, L. J., et al. (2006). Clarifying the origin of biological abnormalities in PTSD through the study of identical twins discordant for combat exposure. Annals of the New York Academy of Sciences, 1071(1), 242-254.

Porter, A. C., \& Felder, C. C. (2001). The endocannabinoid nervous system:: Unique opportunities for therapeutic intervention. Pharmacology $\mathcal{E}$ Therapeutics, 90(1), 45-60.

Quirk, G. J., Garcia, R., \& González-Lima, F. (2006). Prefrontal mechanisms in extinction of conditioned fear. Biological Psychiatry, 60(4), 337-343.

Rademacher, D. J., Meier, S. E., Shi, L., Vanessa Ho, W. S., Jarrahian, A., \& Hillard, C. J. (2008). Effects of acute and repeated restraint stress on endocannabinoid content in the amygdala, ventral striatum, and medial prefrontal cortex in mice. Neuropharmacology, 54(1), 108-116.

Rauch, S. L., Shin, L. M., \& Phelps, E. A. (2006). Neurocircuitry models of posttraumatic stress disorder and extinction: Human neuroimaging research--past, present, and future. Biological Psychiatry, 60(4), 376-382.

Ravindran, L. N., \& Stein, M. B. (2009). Pharmacotherapy of PTSD: premises, principles, and priorities. Brain Res, 1293, 24-39.

Reich, C. G., Mohammadi, M. H., \& Alger, B. E. (2008). Endocannabinoid modulation of fear responses: Learning and state-dependent performance effects. Journal of Psychopharmacology, 22(7), 769-777. 
Resstel, L. B. M., Lisboa, S., Aguiar, D., Corrêa, F. M. A., \& Guimaraes, F. (2008). Activation of CB1 cannabinoid receptors in the dorsolateral periaqueductal gray reduces the expression of contextual fear conditioning in rats. Psychopharmacology, 198(3), 405411.

Reynolds, S. M., \& Berridge, K. C. (2002). Positive and negative motivation in nucleus accumbens shell: Bivalent rostrocaudal gradients for GABA-elicited eating, taste "liking" / "disliking" reactions, place preference/avoidance, and fear. The Journal of Neuroscience, 22(16), 7308-7320.

Ribeiro, A., Ferraz-de-Paula, V., Pinheiro, M., \& Palermo-Neto, J. (2009). Dose-response effects of systemic anandamide administration in mice sequentially submitted to the open field and elevated plus-maze tests. Brazilian Journal of Medical and Biological Research, 42, 556-560.

Robinson, L., Hinder, L., Pertwee, R. G., \& Riedel, G. (2003). Effects of $\Delta$ 9-THC and WIN55,212-2 on place preference in the water maze in rats. Psychopharmacology, 166(1), 40-50.

Richter-Levin, G., \& Akirav, I. (2003). Emotional tagging of memory formation--in the search for neural mechanisms. Brain Research Reviews, 43(3), 247-256.

Robbins, T. W. (2005). Chemistry of the mind: Neurochemical modulation of prefrontal cortical function. The Journal of Comparative Neurology, 493(1), 140-146.

Rodriguez de Fonseca, F., Carrera, M. R. A., Navarro, M., Koob, G. F., \& Weiss, F. (1997). Activation of corticotropin-releasing factor in the limbic system during cannabinoid withdrawal. Science, 276(5321), 2050-2054.

Rodriguez de Fonseca, F., Rubio, P., Menzaghi, F., Merlo-Pich, E., Rivier, J., Koob, G. F., et al. (1996). Corticotropin-releasing factor (CRF) antagonist [D-Phe12, Nle21, 38, C alpha MeLeu37] CRF attenuates the acute actions of the highly potent cannabinoid receptor agonist HU-210 on defensive-withdrawal behavior in rats. Journal of Pharmacology and Experimental Therapeutics, 276(1), 56-64.

Rolls, E. T., Everitt, B., \& Roberts, A. (1996). The orbitofrontal cortex [and discussion]. Philosophical Transactions of the Royal Society of London.Series B: Biological Sciences, 351(1346), 1433.

Roohbakhsh, A., Moghaddam, A. H., Massoudi, R., \& Zarrindast, M. R. (2007). role of dorsal hippocampal cannabinoid receptors and nitric oxide in anxiety like behaviours in rats using the elevated plus-maze test. Clinical and Experimental Pharmacology and Physiology, 34(3), 223-229.

Ross, R. A. (2003). Anandamide and vanilloid TRPV1 receptors. British Journal of Pharmacology, 140(5), 790-801.

Rothbaum, B. O., \& Davis, M. (2003). Applying learning principles to the treatment of Post-Trauma reactions. Annals of the New York Academy of Sciences, 1008(1), 112-121.

Rubino 2008a. CB1 receptor stimulation in specific brain areas differently modulate anxietyrelated behaviour. Neuropharmacology, 54(1), 151-160.

Rubino 2008b. Role in anxiety behavior of the endocannabinoid system in the prefrontal cortex. Cerebral Cortex, 18(6), 1292-1301.

Rubino, T., Sala, M., Viganò, D., Braida, D., Castiglioni, C., Limonta, V., et al. (2007). Cellular mechanisms underlying the anxiolytic effect of low doses of peripheral $\Delta 9$ tetrahydrocannabinol in rats. Neuropsychopharmacology, 32(9), 2036-2045.

Sapolsky, R. M. (1996). Why stress is bad for your brain. Science, 273(5276), 749-750. 
Scherma, M., Medalie, J., Fratta, W., Vadivel, S. K., Makriyannis, A., Piomelli, D., et al. (2008). The endogenous cannabinoid anandamide has effects on motivation and anxiety that are revealed by fatty acid amide hydrolase (FAAH) inhibition. Neuropharmacology, 54(1), 129-140.

Seamans, J. K., \& Phillips, A. G. (1994). Selective memory impairments produced by transient lidocaine-induced lesions of the nucleus accumbens in rats. Behavioral Neuroscience, 108(3), 456-468.

Setlow, B., Roozendaal, B., \& McGaugh, J. L. (2000). Involvement of a basolateral amygdala complex-nucleus accumbens pathway in glucocorticoid-induced modulation of memory consolidation. European Journal of Neuroscience, 12(1), 367-375.

Sheline, Y. I., Sanghavi, M., Mintun, M. A., \& Gado, M. H. (1999). Depression duration but not age predicts hippocampal volume loss in medically healthy women with recurrent major depression. The Journal of Neuroscience, 19(12), 5034-5043.

Shin and Liberzon, 2010. The neurocircuitry of fear, stress, and anxiety disorders. Neuropsychopharmacology, 35(1), 169-191.

Shors, T. J., Weiss, C., \& Thompson, R. F. (1992). Stress-induced facilitation of classical conditioning. Science, 257(5069), 537-539.

Shumake, J., Barrett, D., \& Gonzalez-Lima, F. (2005). Behavioral characteristics of rats predisposed to learned helplessness: Reduced reward sensitivity, increased novelty seeking, and persistent fear memories. Behavioural Brain Research, 164(2), 222-230.

Skrabek, R. Q., Galimova, L., Ethans, K., \& Perry, D. (2008). Nabilone for the treatment of pain in fibromyalgia. J Pain, 9(2), 164-173.

Steiner, M. A., Marsicano, G., Nestler, E. J., Holsboer, F., Lutz, B., \& Wotjak, C. T. (2008). Antidepressant-like behavioral effects of impaired cannabinoid receptor type 1 signaling coincide with exaggerated corticosterone secretion in mice. Psychoneuroendocrinology, 33(1), 54-67.

Steiner, M. A., \& Wotjak, C. T. (2008). Role of the endocannabinoid system in regulation of the hypothalamic-pituitary-adrenocortical axis. Progress in Brain Research, 170, 397432.

Sullivan, J. M. (2000). Cellular and molecular mechanisms underlying learning and memory impairments produced by cannabinoids. Learning \& Memory, 7(3), 132-139.

Suzuki, A., Josselyn, S. A., Frankland, P. W., Masushige, S., Silva, A. J., \& Kida, S. (2004). Memory reconsolidation and extinction have distinct temporal and biochemical signatures. Journal of Neuroscience, 24(20), 4787-4795.

Svízenská, I., Dubovı, P., \& Sulcová, A. (2008). Cannabinoid receptors 1 and 2 (CB1 and CB2), their distribution, ligands and functional involvement in nervous system structures--a short review. Pharmacology Biochemistry and Behavior, 90(4), 501-511.

Taber, K. H., \& Hurley, R. A. (2009). Endocannabinoids: Stress, anxiety, and fear. Journal of Neuropsychiatry and Clinical Neurosciences, 21(2), 108-113.

Tanda, G., Pontieri, F. E., \& Chiara, G. D. (1997). Cannabinoid and heroin activation of mesolimbic dopamine transmission by a common? 1 opioid receptor mechanism. Science, 276(5321), 2048.

Tremblay, L., \& Schultz, W. (1999). Relative reward preference in primate orbitofrontal cortex. Nature, 398(6729), 704-708. 
Tsou, K., Brown, S., Saņudo-Peņa, M., Mackie, K., \& Walker, J. (1997). Immunohistochemical distribution of cannabinoid CB1 receptors in the rat central nervous system. Neuroscience, 83(2), 393-411.

Urigüen, L., Pérez-Rial, S., Ledent, C., Palomo, T., \& Manzanares, J. (2004). Impaired action of anxiolytic drugs in mice deficient in cannabinoid CB1 receptors. Neuropharmacology, 46(7), 966-973.

Varvel et al., 2007. Inhibition of fatty-acid amide hydrolase accelerates acquisition and extinction rates in a spatial memory task. Neuropsychopharmacology, 32(5), 1032-1041.

Varvel, S., Anum, E., \& Lichtman, A. (2005). Disruption of CB 1 receptor signaling impairs extinction of spatial memory in mice. Psychopharmacology, 179(4), 863-872.

Vianna, M. R., Coitinho, A. S., \& Izquierdo, I. (2004). Role of the hippocampus and amygdala in the extinction of fear-motivated learning. Current Neurovascular Research, 1(1), 55-60.

Viveros, M., Marco, E., Llorente, R., \& Lopez-Gallardo, M. (2007). Endocannabinoid system and synaptic plasticity: Implications for emotional responses. Neural Plasticity, 52908.

Viveros, M., Marco, E. M., \& File, S. E. (2005). Endocannabinoid system and stress and anxiety responses. Pharmacology Biochemistry and Behavior, 81(2), 331-342.

Wade, M. R., Degroot, A., \& Nomikos, G. G. (2006). Cannabinoid CB1 receptor antagonism modulates plasma corticosterone in rodents. European Journal of Pharmacology, 551(1-3), 162-167.

Wessa, M., \& Flor, H. (2007). Failure of extinction of fear responses in posttraumatic stress disorder: evidence from second-order conditioning. American Journal of Psychiatry, 164(11), 1684-92.

Willner, P., Muscat, R., \& Papp, M. (1992). Chronic mild stress-induced anhedonia: A realistic animal model of depression. Neuroscience \& Biobehavioral Reviews, 16(4), 525-534.

Windle, M., \& Wiesner, M. (2004). Trajectories of marijuana use from adolescence to young adulthood: Predictors and outcomes. Development and Psychopathology, 16(04), 10071027.

Woon, F. L., \& Hedges, D. W. (2008). Hippocampal and amygdala volumes in children and adults with childhood maltreatment-related posttraumatic stress disorder: A meta-analysis. Hippocampus, 18(8), 729-736.

Zangen, A., Nakash, R., Overstreet, D. H., \& Yadid, G. (2001). Association between depressive behavior and absence of serotonin-dopamine interaction in the nucleus accumbens. Psychopharmacologia, 155(4), 434-439. 


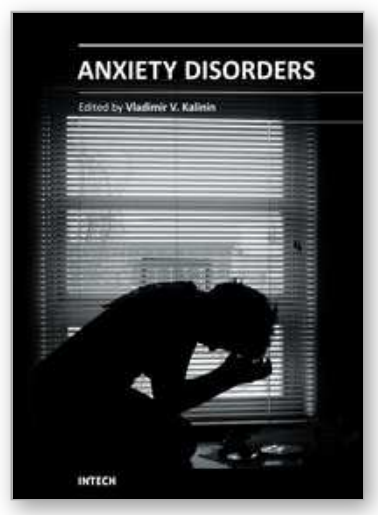

\author{
Anxiety Disorders \\ Edited by Prof. Vladimir Kalinin
}

ISBN 978-953-307-592-1

Hard cover, 324 pages

Publisher InTech

Published online 01, August, 2011

Published in print edition August, 2011

During the last 2-3 decades drastic research progress in anxiety issues has been achieved. It concerns mostly the study of different subtypes of anxiety and their treatment. Nevertheless, the data on anxiety pathogenesis is less elaborated, although here a multidimensional approach exists. It includes neurochemistry, pathophysiology, endocrinology and psychopharmacology. Again, we are able to recognize the multifarious sense of anxiety, and the present collective monograph composed of 16 separate chapters depicting the different aspects of anxiety. Moreover, a great part of book includes chapters on neurochemistry, physiology and pharmacology of anxiety. The novel data on psychopathology and clinical signs of anxiety and its relationship with other psychopathological phenomena is also presented. The current monograph may represent an interest and be of practical use not only for clinicians but for a broad range of specialists, including biochemists, physiologists, pharmacologists and specialists in veterinary.

\title{
How to reference
}

In order to correctly reference this scholarly work, feel free to copy and paste the following:

Irit Akirav (2011). Role of the Endocannabinoid System in Anxiety and Stress-Related Disorders, Anxiety Disorders, Prof. Vladimir Kalinin (Ed.), ISBN: 978-953-307-592-1, InTech, Available from:

http://www.intechopen.com/books/anxiety-disorders/role-of-the-endocannabinoid-system-in-anxiety-andstress-related-disorders 1

\section{INTECH}

open science | open minds

\section{InTech Europe}

University Campus STeP Ri

Slavka Krautzeka 83/A

51000 Rijeka, Croatia

Phone: +385 (51) 770447

Fax: +385 (51) 686166

www.intechopen.com

\section{InTech China}

Unit 405, Office Block, Hotel Equatorial Shanghai

No.65, Yan An Road (West), Shanghai, 200040, China

中国上海市延安西路65号上海国际贵都大饭店办公楼 405 单元

Phone: +86-21-62489820

Fax: $+86-21-62489821$ 
(C) 2011 The Author(s). Licensee IntechOpen. This chapter is distributed under the terms of the Creative Commons Attribution-NonCommercialShareAlike-3.0 License, which permits use, distribution and reproduction for non-commercial purposes, provided the original is properly cited and derivative works building on this content are distributed under the same license. 